Ian S. E. Carmichael • Holli M. Frey •

Rebecca A. Lange • Chris M. Hall

\title{
The Pleistocene cinder cones surrounding Volcán Colima, Mexico re-visited: eruption ages and volumes, oxidation states, and sulfur content
}

Received: 16 August 2004 / Accepted: 18 May 2005 / Published online: 28 January 2006

(C) Springer-Verlag 2005

\begin{abstract}
Located at the volcanic front in the western Mexican arc, in the Colima Rift, is the active Volcán Colima, which lies on the southern end of the massive $\left(\sim 450 \mathrm{~km}^{3}\right)$ Colima-Nevado volcanic complex. Along the margins of this andesitic volcanic complex, is a group of 11 scoria cones and associated lavas, which have been dated by the ${ }^{40} \mathrm{Ar} /{ }^{39} \mathrm{Ar}$ method. Nine scoria cones erupted $\sim 1.3 \mathrm{~km}^{3}$ of alkaline magma (basanite, leucite-basanite, minette) between 450 and $60 \mathrm{ka}$, with $>99 \%$ between 240 and $60 \mathrm{ka}$. Two additional cones (both the oldest and calc-alkaline) erupted $<0.003 \mathrm{~km}^{3}$ of basalt $(0.5 \mathrm{Ma})$ and $<0.003 \mathrm{~km}^{3}$ of basaltic andesite (1.2 Ma), respectively. Cone and lava volumes were estimated with the aid of digital elevation models (DEMs). The eruption rate for these scoria cones and their associated lavas over the last $1.2 \mathrm{Myr}$ is $\sim 1.2 \mathrm{~km}^{3} / \mathrm{Myr}$, which is more than 400 times smaller than that from the andesitic Colima-Nevado edifice. In addition to these alkaline Colima cones, two other potassic basalts erupted at the volcanic front, but $\sim 200 \mathrm{~km}$ to the ESE (near the historically active Volcán Jorullo), and were dated at 1.06 and $0.10 \mathrm{Ma}$. These potassic suites reflect the tendency in the west-central Mexican arc for magmas close to the volcanic front to be enriched in $\mathrm{K}_{2} \mathrm{O}$ relative to those farther from the trench.

Ferric-ferrous analyses on pristine samples from the alkaline cones adjacent to V. Colima and V. Jorullo indicate that
\end{abstract}

Electronic Supplementary Material Supplementary material is available for this article at

http://dx.10.1007/s00445-005-0015-8

Editorial responsibility: J. Donnelly-Nolan

I. S. E. Carmichael $(\bowtie)$

Department of Earth and Planetary Science, University of California

307 McCone Hall, Berkeley, CA 94720

e-mail: ian@eps.berkeley.edu

Tel.: 510-642-2577

Fax: 510-643-9980

H. M. Frey · R. A. Lange · C. M. Hall

Department of Geological Sciences, University of Michigan,

2534 C.C. Little Building, Ann Arbor, MI 48109 their oxygen fugacities relative to the nickel-nickel oxide buffer are significantly higher $(\triangle N N 0=2-4)$ than those for the calc-alkaline magma types $(0-1.5)$. These $\Delta$ NNO values correlate positively with Ba concentrations and likely reflect the influence of a slab-derived fluid. As a result of the high oxidation states, the solubility of sulfur in these potassic magmas is enhanced. Indeed the sulfur content of both the whole rock and the apatite phenocrysts (and in olivine melt inclusions reported in the literature) suggest that part of their pre-eruptive sulfur gas $\left(\mathrm{SO}_{2}\right)$ concentrations could have been discharged to the atmosphere in amounts comparable to the 1982 eruption of El Chichón, although over a prolonged period spanning thousands of years (not per eruption).

\section{Introduction}

The west-central Mexican volcanic arc is related to subduction of the Rivera and Cocos plates beneath the North American Plate along the Middle America Trench (Fig. 1). The tectonics of the upper plate are dominated by three intersecting rift systems: (1) the $\mathrm{N}-\mathrm{W}$ trending TepicZacoalco Rift, (2) the N-S trending Colima Rift, and (3) the E-W Chapala Rift that contains Lake Chapala (Fig. 1). Within the Colima Rift is a massive, southward-younging chain of three andesitic, composite volcanoes (Figs. 1 and 2). The active Volcán Colima is found at the southernmost end of this complex, whereas $5 \mathrm{~km}$ to the north is the larger Pleistocene volcano, Nevado de Colima (Fig. 2). In combination, the Colima-Nevado volcanic edifice has a volume of $\sim 450 \mathrm{~km}^{3}$, and the surrounding volcaniclastic apron has a comparable volume (Luhr and Carmichael 1980). Approximately $15 \mathrm{~km}$ farther north is the eroded andesitic/dacitic volcanic center of Cerro El Cántaro.

Along the northern margin of the Colima-Nevado edifice is a group of 10 cinder cones (Fig. 2); an 11th cone is $\sim 10 \mathrm{~km} \mathrm{~N}$ off the map in Fig. 2. Nine of the 11 scoria cones are made of alkaline rock types (basanite, leucitebasanite, and minette), whereas two are calc-alkaline scoria 


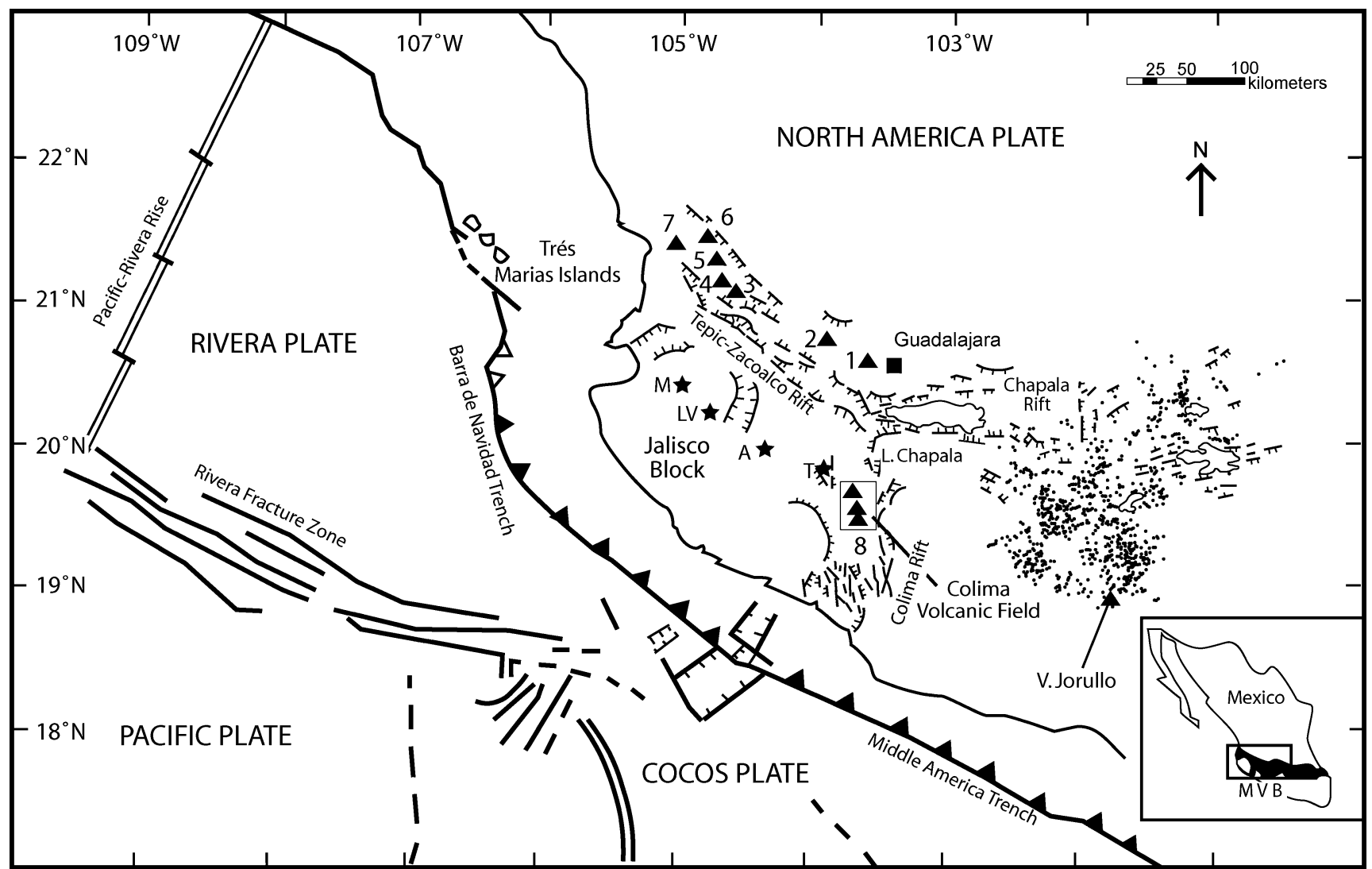

Fig. 1 General tectonic and geologic map of western Mexico, modified from Delgado-Granados (1993). Numbered triangles in the Tepic-Zacoalco and Colima grabens refer to central volcanoes of the Mexican Volcanic Belt: (1) Sierra La Primavera, (2) V. Tequila, (3) V. Ceboruco, (4) V. Tepetiltic, (5) V. Sanganguey, (6) V. Las Navajas, (7) V. San Juan, and (8) V. Colima-Nevado. The Michoacán-Guanajuato

cones of basaltic andesite and basalt, respectively (Luhr and Carmichael 1981). Collectively, the alkaline cones and their associated lavas stand in remarkable compositional and mineralogical contrast to the plagioclase-abundant lavas of the andesitic stratovolcanoes.

Alkaline, phlogopite-bearing cinder cones and associated lavas are also found (near the towns of Mascota, Los Volcanes, Ayutla, and Tapalpa) within interior extensional grabens of the Jalisco Block, which is bounded by the Tepic-Zacoalco Rift, the Colima Rift and the Middle America Trench (Fig. 1; Carmichael et al. 1996; Wallace and Carmichael 1992a; Righter and Rosas-Elguera 2001). In addition to this clear association of alkaline volcanic rocks with grabens of the Jalisco Block, potassic magmas also erupted $\sim 200 \mathrm{~km}$ to the ESE along the volcanic front. Here, close to the historically active cone of Jorullo (Fig. 1; Luhr and Carmichael 1985), a trachybasalt with hornblende \pm phlogopite phenocrysts erupted at Cerro La Pilita.

When the 11 scoria cones adjacent to the andesitic stratovolcanoes of Volcán Colima and Nevado de Colima were first mapped and described more than 20 years ago (Luhr and Carmichael 1981), there were no radiometric dates for any of the scoria or associated lavas. Nor were there any radiometric dates for the andesite volcanoes themselves. volcanic field (MGVF) consists of numerous vents, represented by solid dots. V. Jorullo is a cinder cone at the volcanic front within the MGVF. Tectonic elements are from DeMets and Stein (1990) and Johnson and Harris (1990). The letters $M, L V, A$, and $T$ refer to the towns of Mascota, Los Volcanes, Ayutla and Tapalpa, respectively

Subsequently, four K-Ar ages published by Allan (1986) show that the Cantaro volcanic complex was active at $\sim 1-$ 1.5 Ma, whereas seven K-Ar ages reported by Robin et al. (1987) indicate that Nevado de Colima was active between $\sim 0.53$ and $\sim 0.08 \mathrm{Ma}$. These dates lead to the question: Were these 11 cinder cones erupted over a relatively broad time interval, spanning the last $1 \mathrm{Myr}$ and contemporaneous with the entire history of andesitic volcanism in the Colima Rift? Or, alternatively, were the 11 cones erupted over a relatively narrow and recent interval (e.g., over the last $40 \mathrm{kyr}$ ) as initially suggested by Luhr and Carmichael (1981)? To address these issues, we used the laser-heated ${ }^{40} \mathrm{Ar} /{ }^{39} \mathrm{Ar}$ technique to date 12 samples from these 11 cones and their associated lavas. We combine these dates with estimates of erupted volumes using digital elevation models (DEMs) and ortho airphotos so that a more precise eruption rate for these mantle-derived, potassic magmas can be obtained.

Other questions relate to the oxidation state and sulfur concentrations of these magmas, and whether there was a significant release of $\mathrm{SO}_{2}$ during their eruption. Although the cones are small in volume, some have associated flows that, in aggregate, may rival the erupted volume $\left(\sim 0.4 \mathrm{~km}^{3}\right)$ of the sulfur-rich and oxidized magma from El 


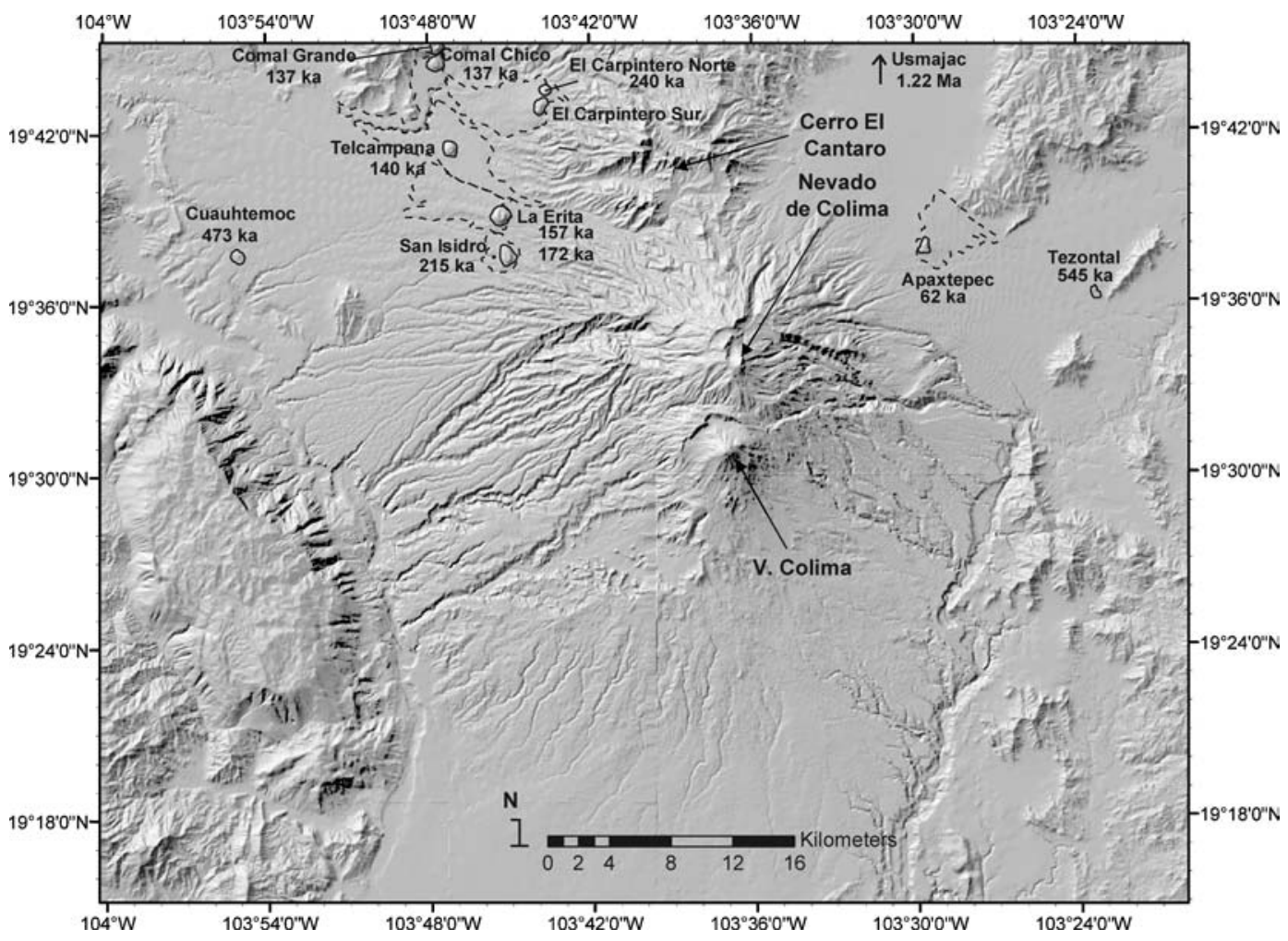

Fig. 2 Shaded hillside digital elevation model (scale 1:20,000) of the Colima volcanic field. Individual cinder cones are outlined in heavy black lines, whereas associated lava flows are outlined by dashed

Chichón in eastern Mexico in 1982 (Luhr et al. 1984). If the scoria cones with associated lavas (e.g., Telcampana, La Erita, El Carpintero Norte, Apaxtepec; Fig. 2) were erupted contemporaneously, it is possible that they released a comparable mass of $\mathrm{SO}_{2}$ into the atmosphere as the $\mathrm{El}$ Chichón eruption. Thus, another goal of this study is to determine both the oxidation states and sulfur concentrations in the scoria and lava erupted from these cones. At the time of the previous study (Luhr and Carmichael 1981), it was not appreciated that analyses of ferric-ferrous ratios in unaltered lava and scoria samples could be used to reveal the equilibrium magmatic oxygen fugacity of the quenched magmas (Carmichael 1991). We use this approach to test whether these alkaline magmas are highly oxidized, and if so, how it affected sulfur behavior prior to and during eruption.

\section{Composition of scoria and lavas}

\section{Colima cones}

All of the recollected samples from the Colima cones fall within the same petrographic groups found 20 years ago, and are summarized here. The mafic alkaline suite forms a complete transitional range from basanite through leucitebasanite to minette, and the characteristic mineral assemblage of each type is given by Luhr and Carmichael (1981). A strikingly fresh and vesicular lava from La Erita (1015, lines. Ages are shown in kilo years (kyr) and are the isochron ages from Table 3

Table 1) is exposed in a new road cut, so this sample of leucite basanite is an addition to the inventory of samples from the Colima cones. The nomenclature used in 1981 defines basanite as having olivine ( $\mathrm{Fo}_{94}-\mathrm{Fo}_{87}$, plus chromite) phenocrysts together with less abundant or rare plagioclase and augite phenocrysts. In addition to olivine and augite, the leucite-basanites contain leucite phenocrysts, and the minettes have phlogopite phenocrysts and apatite microphenocrysts.

The two calc-alkaline cones, Tezontal (sample 22E) and Usmajac (sample 1002), are morphologically similar to the alkaline cones, and lie on the northeastern side of the Nevado-Colima volcanic complex (Fig. 2). The Usmajac cone (basaltic andesite) is just off the map in Fig. 2 to the north. The most significant feature of the Tezontal cone is that it erupted basaltic scoria (Table 1), one of the very few young examples of calc-alkaline basalt $\left(<52 \mathrm{wt} . \% \mathrm{SiO}_{2}\right)$ to occur in western Mexico (Luhr et al. 1989). This cone almost completely comprises red oxidized scoria; however, a small outcrop of black scoria was found within the quarry and sampled for this study.

Twelve unaltered, recollected samples from the Colima cones and lavas were analyzed for major and trace elements by X-ray fluorescence (XRF) at the University of California, Berkeley, and the results are reported in Table 1. Previously, multiple samples from each of the cones of Apaxtepec, Telcampana, Comal Chico, San Isidro, and La Erita (Fig. 2) were analyzed by Luhr and Carmichael (1981, see key to sample localities in Appendix 1), and 


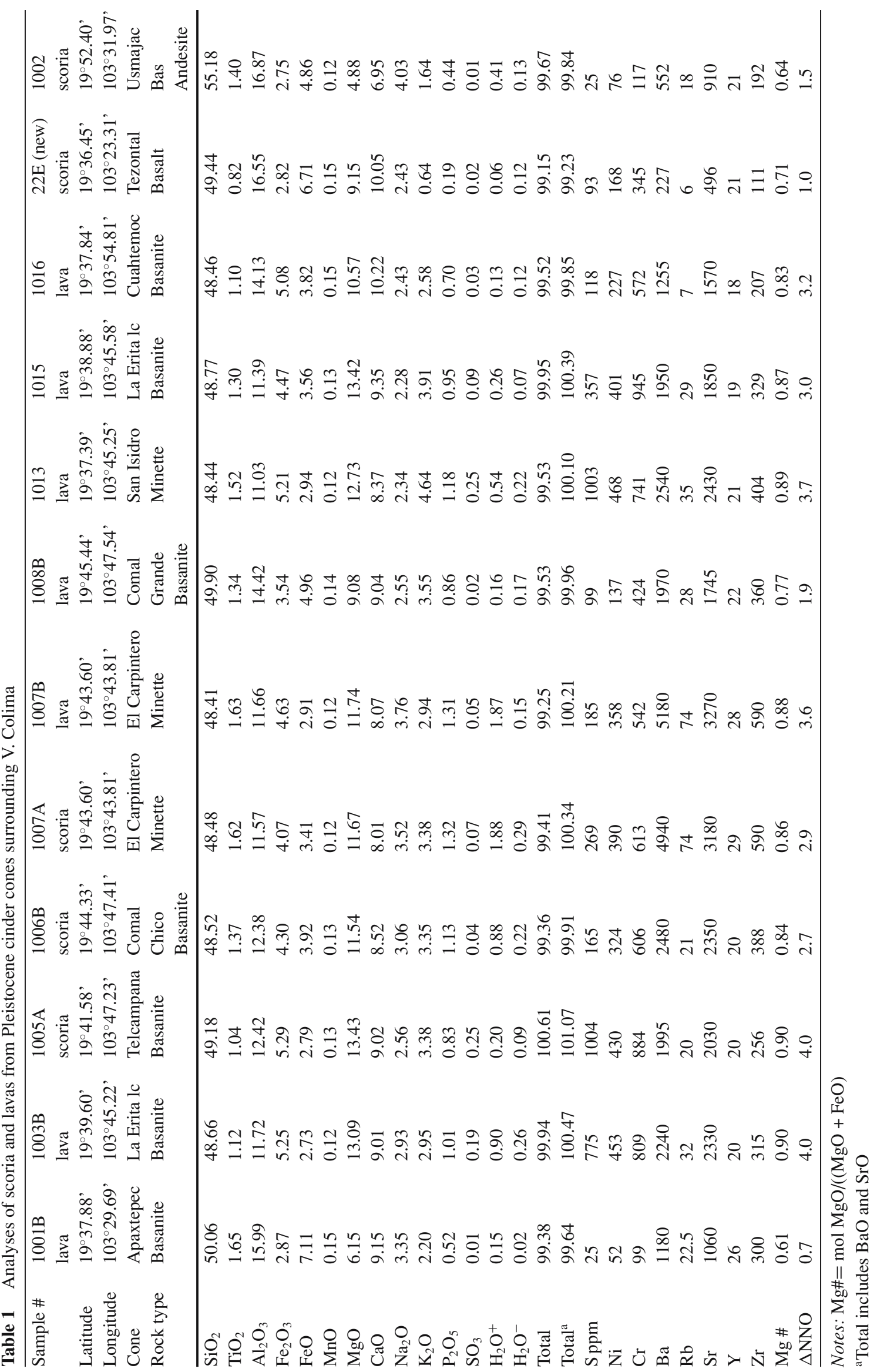


considerable variation was found, so it is unlikely that the new analyses given in Table 1 will necessarily reproduce the compositions of each of the cones published by Luhr and Carmichael (1981). To reduce analytical uncertainty, the original wet chemically analyzed samples (Luhr and Carmichael 1981) were used as XRF standards to calibrate the working curves for the new samples.

$\mathrm{Mg} \#(\mathrm{MgO} / \mathrm{MgO}+\mathrm{FeO})$ values are high $(0.61-0.90)$, with correspondingly high $\mathrm{Ni}$ and $\mathrm{Cr}$ contents (52-470 ppm and $99-945 \mathrm{ppm}$, respectively), indicative of a primary mantle origin for most of the samples (Luhr and Carmichael 1981). $\mathrm{K}_{2} \mathrm{O}$ ranges from 2.2-4.6 wt.\%, with correspondingly high concentrations in the alkaline samples of $\mathrm{Ba}$ $(1,200-5,200 \mathrm{ppm}), \mathrm{Sr}(1,100-3,300 \mathrm{ppm})$, and $\mathrm{Zr}(250$ $600 \mathrm{ppm}$ ), which if converted to oxides, and added into the analyses in Table 1, gives totals closer to $100 \mathrm{wt} . \%$. The basanites tend to have lower $\mathrm{P}_{2} \mathrm{O}_{5}(<1$ wt.\%) than the leucite-basanites, with the minettes typically having 1.2-1.3 wt. $\% \mathrm{P}_{2} \mathrm{O}_{5}$, with $\mathrm{TiO}_{2}$ following $\mathrm{P}_{2} \mathrm{O}_{5}$ in this alkaline suite. In Table 1, we also present total sulfur (S) concentrations for each sample. The XRF technique gave a $S$ concentration of $482 \pm 4.1 \mathrm{ppm}$ for eight analyses of the standard rock BCR-1, which has a recommended S concentration of $410 \mathrm{ppm}$. On the basis of multiple analyses, the following precision $( \pm 1 \sigma)$ was obtained: $1004 \pm 43 \mathrm{ppm} \mathrm{S}$ for sample 1005A and $25 \pm 1.7 \mathrm{ppm} \mathrm{S}$ for sample 1001B (Table 1).

\section{Potassic lavas adjacent to V. Jorullo}

Volcán Colima is close to the Middle America Trench, and in that sense defines the present volcanic front in this part of the Mexican arc (Fig. 1). Historic Volcán Jorullo (1759-1774) defines the volcanic front farther to the east in the state of Michoacán (Fig. 1). The earliest lava associated with this historical eruption is a high- $\mathrm{Mg}$ basaltic andesite (Table 2, JOR 44) and successive lavas became increasingly Mg-poor as hornblende became a late-stage phenocryst (Luhr and Carmichael 1985). However, V. Jorullo was preceded by the nearby late-Pleistocene sulfate-rich alkali basalt scoria cone (Cerro La Pilita) and lava (Table 2, JOR 46d). An older cone (unnamed and near Mesa Agua Caliente), which is marginally closer to the Middle America Trench (13 km to the WSW of Cerro La Pilita),

Table 2 Analyes of scoria and lavas from Pleistocene cinder cones surrounding V. Jorullo

\begin{tabular}{|c|c|c|c|c|}
\hline Sample \# & $\begin{array}{l}\text { Mas } 2001 \\
\text { lava }\end{array}$ & $\begin{array}{l}\text { Jor } 44 \\
\text { lava }\end{array}$ & $\begin{array}{l}\text { Mas 2003a } \\
\text { scoria }\end{array}$ & $\begin{array}{l}\text { Jor } 46 d \\
\text { lava }\end{array}$ \\
\hline Latitude & $18^{\circ} 56.30^{\prime}$ & $18^{\circ} 59.49^{\prime}$ & $18^{\circ} 56.68^{\prime}$ & $18^{\circ} 55.86^{\prime}$ \\
\hline Longitude & $101^{\circ} 50.28^{\prime}$ & $101^{\circ} 45.14^{\prime}$ & $101^{\circ} 43.74^{\prime}$ & $101^{\circ} 44.68^{\prime}$ \\
\hline Cone Rock type & Unnamed basalt & Jorullo Bas. andesite & La Pilita minette & La Pilita trachybasalt \\
\hline $\mathrm{SiO}_{2}$ & 50.44 & 52.10 & 49.04 & 51.72 \\
\hline $\mathrm{TiO}_{2}$ & 1.26 & 0.81 & 1.31 & 1.22 \\
\hline $\mathrm{Al}_{2} \mathrm{O}_{3}$ & 15.76 & 16.44 & 13.46 & 15.12 \\
\hline $\mathrm{Fe}_{2} \mathrm{O}_{3}$ & 3.11 & 1.56 & 5.12 & 4.28 \\
\hline $\mathrm{FeO}$ & 5.94 & 6.05 & 3.17 & 3.47 \\
\hline $\mathrm{MnO}$ & 0.14 & 0.14 & 0.14 & 0.12 \\
\hline $\mathrm{MgO}$ & 8.34 & 9.29 & 8.07 & 8.03 \\
\hline $\mathrm{CaO}$ & 8.78 & 8.46 & 8.73 & 7.45 \\
\hline $\mathrm{Na}_{2} \mathrm{O}$ & 3.79 & 3.47 & 4.06 & 4.55 \\
\hline $\mathrm{K}_{2} \mathrm{O}$ & 1.38 & 0.74 & 3.43 & 2.54 \\
\hline $\mathrm{P}_{2} \mathrm{O}_{5}$ & 0.45 & 0.14 & 1.59 & 0.90 \\
\hline $\mathrm{SO}_{3}$ & 0.01 & 0.00 & 0.59 & 0.02 \\
\hline $\mathrm{H}_{2} \mathrm{O}^{+}$ & 0.13 & 0.34 & 0.70 & 0.43 \\
\hline $\mathrm{H}_{2} \mathrm{O}^{-}$ & 0.23 & 0.10 & 0.32 & 0.04 \\
\hline Total & 99.76 & 99.64 & 99.83 & 99.89 \\
\hline Total $^{\mathrm{a}}$ & 99.92 & 99.71 & 100.44 & 100.25 \\
\hline S ppm & 56 & 14 & 2350 & 98 \\
\hline $\mathrm{Ni}$ & 189 & 261 & 202 & 221 \\
\hline $\mathrm{Cr}$ & 306 & 564 & 303 & 329 \\
\hline $\mathrm{Ba}$ & 545 & 231 & 2310 & 1130 \\
\hline $\mathrm{Rb}$ & 22 & 10 & 8 & 19 \\
\hline $\mathrm{Sr}$ & 801 & 397 & 3002 & 1984 \\
\hline$Y$ & 22 & 20 & 20 & 18 \\
\hline $\mathrm{Zr}$ & 150 & 100 & 236 & 183 \\
\hline $\mathrm{Mg} \#$ & 0.71 & 0.73 & 0.82 & 0.80 \\
\hline$\triangle \mathrm{NNO}$ & 1.3 & -0.2 & 3.5 & 3.0 \\
\hline
\end{tabular}

Notes: $\mathrm{Mg \#}=\mathrm{mol} \mathrm{MgO} /(\mathrm{MgO}+\mathrm{FeO})$

${ }^{a}$ Total includes $\mathrm{BaO}$ and $\mathrm{SrO}$ 
Table $3{ }^{40} \mathrm{Ar} /{ }^{39} \mathrm{Ar}$ ages of scoria and lavas associated with Volcán Colima and Volcán Jorullo

\begin{tabular}{|c|c|c|c|c|c|c|c|c|c|}
\hline Sample & Cinder cone & $\begin{array}{l}\text { Total gas } \\
\text { age (ka) }\end{array}$ & $\begin{array}{l}\text { Isochron } \\
\text { age (ka) }\end{array}$ & MSWD & $\left({ }^{40} \mathrm{Ar} /{ }^{36} \mathrm{Ar}\right)_{\mathrm{I}}$ & Points fitted & $\begin{array}{l}\text { Plateau Age } \\
\text { (ka) }\end{array}$ & MSWD & $\%^{39} \mathrm{Ar}$ \\
\hline 1002 & Usmajac & $1216 \pm 31$ & $1217 \pm 92$ & 1.43 & $295.4 \pm 5.5$ & 13 of 13 & $1160 \pm 26$ & 0.89 & 75 \\
\hline $22 \mathrm{E}$ & Tezontal & $367 \pm 86$ & $545 \pm 144$ & 1.38 & $289.2 \pm 4.4$ & 13 of 13 & N/A & N/A & N/A \\
\hline 1016 & Cuahtemoc & $454 \pm 14$ & $473 \pm 21$ & 2.39 & $301.2 \pm 6.5$ & 13 of 13 & $449 \pm 16$ & 0.48 & 54 \\
\hline 1007A & El Carpintero Norte & $257 \pm 16$ & $240 \pm 27$ & 0.98 & $303.4 \pm 3.9$ & 13 of 13 & $231 \pm 17$ & 0.48 & 75 \\
\hline 1013 & San Isidro & $109 \pm 9$ & $215 \pm 18$ & 0.72 & $294.1 \pm 2.9$ & 9 of 13 & $171 \pm 1$ & 0.66 & 75 \\
\hline 1015 & La Erita (major cone) & $-23 \pm 30$ & $157 \pm 15$ & 3.30 & $294.1 \pm 2.9$ & 13 of 13 & $76 \pm 29$ & 4.00 & 80 \\
\hline 1003B & La Erita (minor cone) & $157 \pm 20$ & $172 \pm 21$ & 0.71 & $298.4 \pm 3.7$ & 9 of 13 & $147 \pm 16$ & 0.71 & 80 \\
\hline $1005 \mathrm{~A}$ & Telcampana & $155 \pm 10$ & $140 \pm 13$ & 1.58 & $297.5 \pm 1.1$ & 13 of 13 & $154 \pm 12$ & 1.87 & 88 \\
\hline 1006B & Comal Chico & $126 \pm 8$ & $137 \pm 11$ & 0.82 & $311.6 \pm 8.2$ & 13 of 13 & $110 \pm 8$ & 0.11 & 70 \\
\hline 1008B & Comal Grande & $99 \pm 8$ & $137 \pm 12$ & 0.33 & $297.6 \pm 5.8$ & 13 of 13 & $105 \pm 7$ & 0.34 & 100 \\
\hline 1001B & Apaxtepec & $82 \pm 15$ & $62 \pm 14$ & 2.90 & $298.5 \pm 1.1$ & 13 of 13 & $51 \pm 5$ & 0.13 & 58 \\
\hline $1004-500$ & Apaxtepec & $40 \pm 19$ & $53 \pm 14$ & 1.72 & $288.2 \pm 7.5$ & 13 of 13 & $66 \pm 18$ & 1.49 & 87 \\
\hline Mas 2001 & Unnamed & $1110 \pm 27$ & $1060 \pm 47$ & 1.41 & $304.5 \pm 12.6$ & 13 of 13 & $1080 \pm 24$ & 1.34 & 96 \\
\hline Jor 46d & Cerro La Pilita & $160 \pm 18$ & $102 \pm 20$ & 0.64 & $298.4 \pm 2.0$ & 13 of 13 & $160 \pm 15$ & 0.77 & 100 \\
\hline
\end{tabular}

All errors are reported as 1 sigma. Monitor was Fish Canyon Tuff biotite-split 3 (27.99 Ma)

Latitude and longitude of specimens are given in Tables 1 and 2. Preferred ages are isochron ages

erupted basalt with 1.4 wt.\% $\mathrm{K}_{2} \mathrm{O}$ (Table 2, MAS 2001). The compositions of these two basalts (sensu lato) reflect one of the curiosities of the pattern of volcanism in the west-central Mexican Volcanic Belt, namely the tendency for contemporaneous lavas close to the volcanic front to be enriched in $\mathrm{K}_{2} \mathrm{O}$ relative to those farther from the trench (Blatter et al. 2001).

\section{${ }^{40} \mathrm{Ar} /{ }^{39} \mathrm{Ar}$ geochronology}

Methods

Ages for 11 Colima cones and two scoria cones near V. Jorullo were determined by the ${ }^{40} \mathrm{Ar} /{ }^{39} \mathrm{Ar}$ laser ablation step-heating method and are given in Table 3. All analyses were run at the University of Michigan, and the procedures closely followed those described in Hall and Farrell (1995) and Frey et al. (2004). Samples were taken from the interiors of lava flows or the inner cores of dense volcanic bombs from cinder cones, and each sample was checked for alteration using a petrographic microscope. For each sample, groundmass separates were handpicked for irradiation with fast neutrons for $6 \mathrm{~h}$ at the Phoenix-Ford Memorial Reactor at the University of Michigan. Fish Canyon Tuff biotite split-3 (FCT-3) was used as a neutron-fluence monitor and yielded a K-Ar age of $27.99 \pm 0.04 \mathrm{Ma}$ (2 sigma), relative to 520.4 Ma for MMhb-1 (Hall and Farrell 1995; Samson and Alexander 1987). This age is comparable to the $28.02 \pm 0.09 \mathrm{Ma}$ age reported by Renne et al. (1998). Additional details of the procedures that were followed are given in Frey et al. (2004).

Results

The ${ }^{40} \mathrm{Ar} /{ }^{39} \mathrm{Ar}$ data analysis for each sample, including gas spectra and inverse isochron diagrams, are given as Elec-

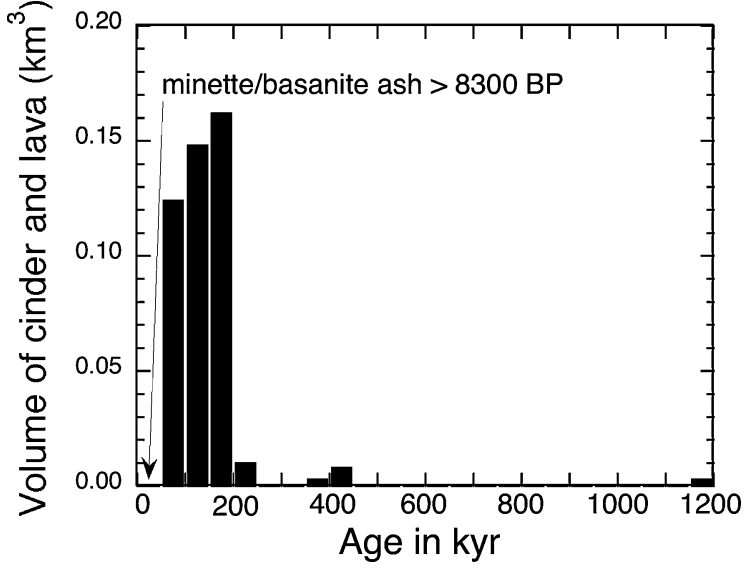

Fig.3 Volumes of lava and scoria, uncorrected to magma equivalent, for the Colima cones plotted against ages of eruptions (Tables 3 and 5)

tronic Supplementary Material (ESM Figs. 1-4). A summary of this information along with total gas, isochron, and plateau ages is reported in Table 3 . The error analysis for each sample includes uncertainties in peak signals, system blanks, spectrometer mass discrimination, reactor corrections, and $J$ values. The error on the plateau age is a standard weighted error for the individual steps by variance (Taylor 1982), i.e., release fractions with more precise results carry greater weight in the age calculation. All but one sample (22E, Tezontal) gave ${ }^{40} \mathrm{Ar} /{ }^{39} \mathrm{Ar}$ release spectra that resulted in a plateau. The isochron ages for all but one (1013, San Isidro) of these 12 samples are within two sigma error of their respective plateau ages. The preferred ages for the samples in Table 3 are the isochron ages, where all but three have MSWDs $<1.8$ (ranging from 0.33 to 3.30).

As a check on our ${ }^{40} \mathrm{Ar} /{ }^{39} \mathrm{Ar}$ method, two different samples from the morphologically youngest scoria cone, Apaxtepec, were dated. The first sample (1004-500; Table 3) is 


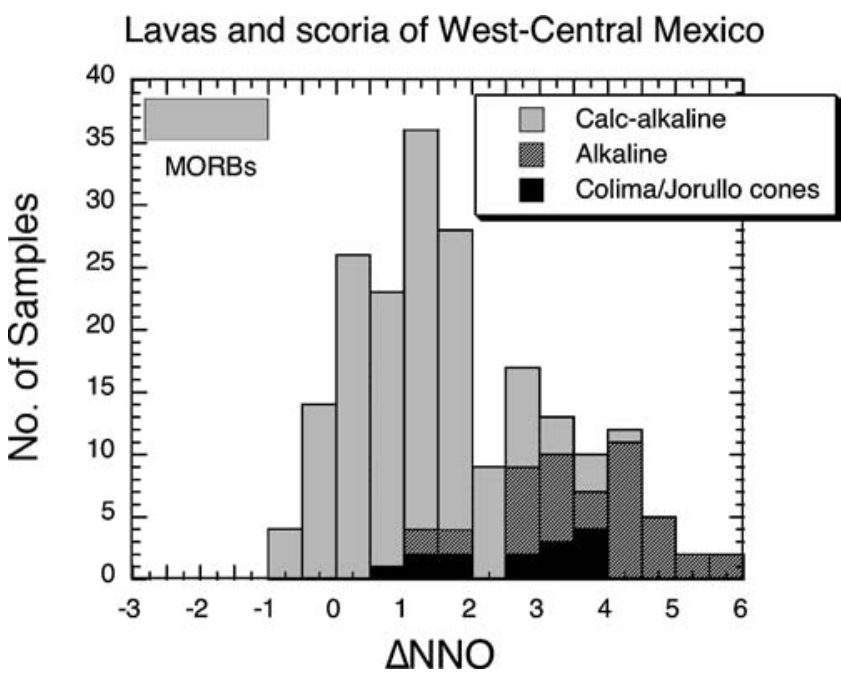

Fig. 4 Plot of $\triangle \mathrm{NNO}$ calculated as described in the text using the analyzed $\mathrm{FeO}$ and $\mathrm{Fe}_{2} \mathrm{O}_{3}$ contents of lavas. Data are taken from Tables 1 and 2, Blatter and Carmichael (1998, 2001), Carmichael et al. (1996), Hasenaka and Carmichael (1987), Luhr and Carmichael (1980, 1981, 1985), Wallace and Carmichael (1999). Data for MORBs are taken from Christie et al. (1986) and Wallace and Carmichael (1992b); there are far more than $\sim 30$ samples of MORBs

that collected by Luhr and Carmichael (1981), whereas the second sample (1001B; Table 3) was collected more than 20 years later. In addition, the two samples were irradiated and laser heated more than 18 months apart. The results give isochron ages $(53 \pm 14 \mathrm{ka} ; 62 \pm 14 \mathrm{ka})$ that average to $58 \pm 10 \mathrm{ka}$ and plateau ages $(66 \pm 18 \mathrm{ka} ; 55 \pm 5 \mathrm{ka})$ that average to $59 \pm 9 \mathrm{ka}$. The dates on the two specimens are fully consistent with each other and indicate an eruption age for the Apaxtepec cone at $\sim 60 \mathrm{ka}$.

Of the 11 Colima cones, the two oldest are the calcalkaline types, the basaltic andesite from the Usmajac cone $(1217 \pm 92 \mathrm{ka})$ and the basalt from Tezontal cone $(545 \pm 144 \mathrm{ka})$. The next eruption produced basanite at the Cuahtemoc cone at $473 \pm 21 \mathrm{ka}$. After a hiatus of $\sim 200 \mathrm{kyr}$, minette erupted as scoria and lava at El Carpintero Norte at $240 \pm 27 \mathrm{ka}$. Between $\sim 200$ and $\sim 60 \mathrm{ka}$, the remaining potassic cones and associated lavas were erupted. The most potassic magma of the Colima cones (minette with 4.64 wt. $\% \mathrm{~K}_{2} \mathrm{O}$ ) was erupted at San Isidro at $215 \pm 18 \mathrm{ka}$. Next, the major and minor cones of La Erita were erupted $(157 \pm 15 \mathrm{ka} ; 172 \pm 21 \mathrm{ka})$; these ${ }^{40} \mathrm{Ar} /{ }^{39} \mathrm{Ar}$ ages (and $1 \sigma \mathrm{er}-$ rors) suggest that these two cones, both of which produced leucite basanite, may have erupted contemporaneously. The average of their dates $(\sim 165 \pm 13 \mathrm{ka})$ likely gives a better estimate of their eruption age, which is close to that for the basanite from Telcampana cone $(140 \pm 13 \mathrm{ka})$. Similarly, the Comal Chico and Comal Grande cones, which erupted basanite magmas of distinctly different composition (Table 1), have indistinguishable eruption ages $(137 \pm 11 \mathrm{ka}$; $137 \pm 12 \mathrm{ka}$ ). The youngest cone, Apaxtepec, erupted at $\sim 60 \mathrm{ka}$, as discussed above.

The two samples of potassic basalt near the historically active cone of V. Jorullo at the volcanic front, ESE of the Colima graben (Fig. 1), were erupted $\sim 1 \mathrm{Myr}$ apart.
The unnamed scoria cone near Mesa Agua Caliente (MAS2001) has an isochron age of $1060 \pm 47 \mathrm{ka}$ and a plateau age of $1080 \pm 24 \mathrm{ka}$, whereas Cerro La Pilita (JOR 46d) has an isochron age of $102 \pm 20 \mathrm{ka}$ and a plateau age of $160 \pm 15 \mathrm{ka}$ (Table 3).

\section{Eruption volumes for Colima cones and associated lavas}

Twenty years ago, the volumes of the cinder cones surrounding Volcán Colima were estimated using geometric simplifications of cones emplaced on horizontal plane surfaces. It is now possible to more accurately calculate volumes of cones and lavas using digital elevation models (DEM) and ortho airphotos as described by Frey et al. (2004). The DEMs and orthophotos use a Universal Transverse Mercator (UTM) projection and the Geodetic Reference System 80 (GRS 80) geodetic model. The lateral and vertical resolution of the DEMs is 50 and $2 \mathrm{~m}$, respectively, based on a 1:50,000 scale, whereas the orthophotos are based on a 1:20,000 scale and have a resolution of $2 \mathrm{~m} / \mathrm{pixel}$. The margins of each cinder cone and associated lava flow were digitized on the orthophotos with the aid of geologic field maps, topographic maps, and Landsat images. From the digitized margins, a three-dimensional representation of the surface topography was created. Cone and lava volume were calculated by the difference of a linear interpolation of this surface and a base level determined from the surrounding topography.

In attempting to quantify eruptive volumes from the cinder cones, an assessment of errors is required. One source of error is the effect of degradation and removal of scoria via erosion over the last 1 Myr. The Colima cinder cones, most of which (8 of 11) are younger than $250 \mathrm{ka}$, range from having smooth flanks to being dissected by small gullies and rills. According to Colton's (1967) scheme of cinder cone degradation, they are classified as stage 5 (youngest) to stage 3 (moderate). Morphometric studies (e.g., Colton 1967; Wood 1980) of cinder cone degradation show that cone heights, height/basal diameter ratios, and flank slopes decrease with cinder cone age. However, crater diameter/basal diameter ratios appear independent of degradation (and composition), suggesting that erosion removes the top of the cone and mass-wasting processes deposit material at the base of the cinder cone (Wood 1980). A compilation of basal and crater diameters and heights for the 11 Colima cones is given in Table 4. For all cones erupted $\leq 250 \mathrm{ka}$ ( 8 of 11), both the height/basal diameter ratios and the crater diameter/basal diameter ratios are very similar. So, although the shapes of cinder cones may change with time, their volumes (as captured by our GIS methods) are conserved to first order.

Another source of error is the amount of tephra erupted from the cones that fell beyond the base of the cone. In the case of the highly explosive Parícutin eruption in Mexico (type example of violent strombolian activity from a cinder cone; Walker 1973), Fries (1953) determined that the volume of tephra that fell beyond Parícutin extended to 8 times the volume of the cone. In contrast, mapped 
Table 4 Dimensions and volumes of cinder cones

Abbr:: $H$ height, $B D$ basal diameter, $C D$ crater diameter

${ }^{a}$ Data from Luhr and Carmichael (1981)

${ }^{\mathrm{b}}$ Two nested craters; two crater diameters are given; their sum is used to calculate $\mathrm{CD} / \mathrm{BD}$

${ }^{\mathrm{c}}$ Includes volume estimate for associated surge beds

\begin{tabular}{lllllll}
\hline Cinder cone & $\mathrm{H}(\mathrm{m})$ & $\mathrm{BD}(\mathrm{m})$ & $\mathrm{CD}(\mathrm{m})$ & $\mathrm{H} / \mathrm{BD}$ & $\mathrm{CD} / \mathrm{BD}$ & $\mathrm{Vol}\left(\mathrm{km}^{3}\right)$ \\
\hline Apaxtepec & 90 & 700 & 250 & 0.13 & 0.36 & 0.013 \\
Comal Chico & 150 & 1,050 & 410 & 0.14 & 0.39 & 0.029 \\
Comal Grande & 180 & 950 & 285 & 0.19 & 0.30 & 0.032 \\
Telcampana & 160 & 935 & 335 & 0.17 & 0.36 & $0.008^{\mathrm{c}}$ \\
La Erita (major) & 260 & 1,335 & 485 & 0.19 & 0.36 & 0.073 \\
San Isidro & 200 & 1,200 & 450 & 0.17 & 0.38 & 0.046 \\
El Carpintero N & 140 & 735 & 275 & 0.19 & 0.38 & 0.010 \\
El Carpintero S & 135 & 975 & $220 / 160^{\mathrm{b}}$ & 0.15 & $0.39^{\mathrm{b}}$ & 0.027 \\
Cuahtemoc & 60 & 925 & 225 & 0.06 & 0.24 & 0.008 \\
Tezontal & 50 & 685 & 130 & 0.08 & 0.19 & 0.003 \\
Usmajac $^{\mathrm{a}}$ & 60 & - & - & - & - & 0.003 \\
\hline
\end{tabular}

Alkaline magma from the Colima cones erupted not only as scoria, but also as associated lava flows. In Table 5, the area of each lava flow field (a set of flows associated with individual cones; Fig. 2) is given, along with a maximum, minimum, and best estimate for the total volume of each set of flows. The total volume is estimated to range from 0.2 to $1.5 \mathrm{~km}^{3}$ (minimum and maximum), with best estimates for individual flow fields that total to $\sim 0.8 \mathrm{~km}^{3}$. Once again, the relative errors on these estimates are large, but the total volumes are sufficiently low compared to the central andesitic volcanism in the Colima graben that robust conclusions contrasting the eruption rates can be drawn (see discussion section). Luhr and Carmichael (1981) do not break down their volume estimates for the various lava flows, but give a total estimate of $\sim 0.2 \mathrm{~km}^{3}$, which is our minimum volume.

\section{Discussion}

Ages, volumes, and eruption rates

Although the morphological ages of the Colima cones estimated by Luhr and Carmichael (1981, Table 1) were all $\leq 40 \mathrm{ka}$, the ${ }^{40} \mathrm{Ar} /{ }^{39} \mathrm{Ar}$ dates in Table 3 range from $1.2 \mathrm{Ma}$ to $60 \mathrm{ka}$. Nonetheless, the relative ages of the cones given by Luhr and Carmichael (1981) are consistent with the ${ }^{40} \mathrm{Ar} /{ }^{39} \mathrm{Ar}$ results. The oldest dated cone (Usmajac, $1217 \pm 92 \mathrm{ka}$ ), NE of Volcan Colima (Fig. 2) is indeed the cone estimated by Luhr and Carmichael (1981) to be the oldest. The oldest cone on the west side of Volcán Colima, Cuauhtemoc (Fig. 2; 473 $\pm 21 \mathrm{ka}$, Table 3), is the only cone that has lake sediments on its lower flanks, but we know

Table 5 Volume of lava flow fields associated with cinder cones

\begin{tabular}{llllll}
\hline Cinder cone & Area $\left(\mathrm{km}^{2}\right)$ & Range in thickness $(\mathrm{m})$ & Min volume $\left(\mathrm{km}^{3}\right)$ & Max volume $\left(\mathrm{km}^{3}\right)$ & Best estimate $\left(\mathrm{km}^{3}\right)$ \\
\hline Apaxtepec & 13.42 & $2-9$ & 0.03 & 0.12 & 0.05 \\
Telcampana & 21.87 & $2-20$ & 0.04 & 0.43 & 0.21 \\
Comal Chico & 10.28 & $2-16$ & 0.02 & 0.16 & 0.12 \\
Comal Grande & 1.99 & $5-10$ & 0.01 & 0.02 & 0.02 \\
El Carpintero & 18.22 & $2-14$ & 0.04 & 0.26 & 0.15 \\
La Erita & 17.25 & $2-21$ & 0.03 & 0.37 & 0.18 \\
San Isidro & 4.26 & $2-26$ & 0.01 & 0.11 & 0.06 \\
Total & & 0.17 & 1.47 & 0.79 \\
\hline
\end{tabular}


that this lake, or its marshy successor, existed at the time that Telecampana (1005A, $140 \pm 13 \mathrm{ka}$ ) erupted because of the occurrence of associated surge beds that are deposited on lake/marsh deposits (Luhr and Carmichael 1981).

The most voluminous of the potassic lavas and scoria, made of minette, leucite-basanite and basanite, all erupted in the interval of $\sim 240-60 \mathrm{ka}$ (Fig. 3; Table 3), which overlaps the period during which calc-alkaline andesites are known to have erupted from the nearby central volcano of Nevado de Colima (Robin et al. 1987); it is presumably the period during which the andesitic cone of the presently active Volcán Colima was being built. Our best estimate for the total volume of potassic magma erupted over the last $250 \mathrm{kyr}$ is $\sim 1.3 \mathrm{~km}^{3}$, which leads to an eruption rate of $\sim 0.005 \mathrm{~km}^{3} / \mathrm{kyr}$. This rate is more than 200 times lower than the cone-building eruption rate of $\geq 1.2 \mathrm{~km}^{3} / \mathrm{kyr}$ for the historically active Volcán Colima, which has produced at least $5 \mathrm{~km}^{3}$ of lava (predominantly andesite) over the last 4.3 kyrs (Luhr and Prestegaard 1988). If the entire history of the Colima cones over the last $1.2 \mathrm{Myr}$ is considered, then the total erupted volume is only incrementally larger at $\sim 1.4 \mathrm{~km}^{3}$, which leads to an average eruption rate of $\sim 0.001 \mathrm{~km}^{3} / \mathrm{kyr}$ or $\sim 1.2 \mathrm{~km}^{3} / \mathrm{Myr}$. This is $\sim 4$ times greater than the eruption rate of $\sim 0.3 \mathrm{~km}^{3} / \mathrm{Myr}$ for lamproite (highly potassic) lavas at the Leucite Hills in Wyoming (Lange et al. 2000), but it is 400-800 times lower than the rate at which andesite/dacite has erupted from the Colima-Nevado complex over the last 1 Myr.

A detailed examination of the ash and scoria deposits on the upper flanks of Volcán Colima by Luhr and Carmichael (1982) showed that basanite/minette magma intermingled with andesitic magma at $\sim 8.3 \mathrm{ka}$. These mixed ashes and scoria were preceded by a thick $(3 \mathrm{~m})$ basanite ash horizon on the volcano that puzzled those authors because of the distances to the most likely young alkaline cones that could be the source of these ashes (La Erita or Cuauhtemoc, 20 and $35 \mathrm{~km}$, respectively; Fig. 2). The new dates (Table 3) establish unequivocally that the mingling of basanite/minette and andesite magma revealed in the ash horizons of Volcán Colima, and the underlying basanite ash layer, are much younger than the nearby scoria cones. Thus, the basanite/minette magma is not from one of these cones, but likely used the fracture system and central vent of Volcán Colima for eruption. Given the number of alkaline eruptions in the Colima graben over the last $250 \mathrm{kyr}$, it is reasonable to expect that this magma type will erupt again, either through the same fracture system feeding Volcán Colima and/or to form another neighboring cone.

\section{Oxidation state of potassic magmas and sulfur release on eruption}

\section{Oxygen fugacity}

In this study, a considerable effort was made to sample fresh unaltered scoria and lava so that the ferric-ferrous ratio of each sample could be used to calculate a magmatic oxygen fugacity. For all the samples reported in Tables 1 and 2, the olivine phenocrysts are pale-green in hand specimens and are without any sign of alteration in thin section (e.g., no bowlingite or iddingsite along the olivine rims). The composition of the olivine phenocrysts in a series of unaltered, Quaternary lavas from Mascota have been shown to be in $\mathrm{FeO}-\mathrm{MgO}$ exchange equilibrium with the host magma by Carmichael et al. (1996), thus confirming the premise that the ferric-ferrous ratios of Quaternary samples, without signs of alteration in thin section, represent magmatic values.

In a multi-component silicate liquid, the ratio $\mathrm{Fe}_{2} \mathrm{O}_{3} / \mathrm{FeO}$ is a function of temperature, composition, and oxygen fugacity at 1 bar. The iron redox state is related to these parameters by the empirical relation:

$$
\ln \left[X_{\mathrm{Fe}_{2} \mathrm{O}_{3}} / X_{\mathrm{FeO}}\right]=a \ln f_{\mathrm{O}_{2}}+b / K+c+\Sigma X d_{i}
$$

where $a, b, c$ and $d_{\mathrm{i}}$ are constants derived by regression of a range of silicate liquids equilibrated from air to the $\mathrm{I}-\mathrm{W}(\mathrm{Fe}-\mathrm{FeO})$ oxygen buffer, over a range of temperatures at 1 bar (Sack et al. 1980; Kilinc et al. 1983; Kress and Carmichael 1988, 1991). Using values of $\mathrm{FeO}$ and $\mathrm{Fe}_{2} \mathrm{O}_{3}$ determined by wet chemistry (Table 1 ), a value of $\ln f_{\mathrm{O}_{2}}$ can be calculated at $1,200{ }^{\circ} \mathrm{C}$, and from this value, the oxygen fugacity defined by the buffer $\mathrm{Ni}-\mathrm{NiO}$ has been subtracted at the same temperature. The result $(\triangle N N O)$ is independent of temperature, and provided that the lava is unaltered (see discussion below), the value will reflect the equilibrium oxygen fugacity required to support the observed redox ratio. The pressure dependence of the oxygen fugacity is small at low pressures (Kress and Carmichael 1991) and has been omitted. Values of oxygen fugacity obtained by this method for Hawaiian lavas are in excellent agreement with those obtained by analyses of volcanic gases (Gerlach 1993), with those obtained from the compositions of coexisting Fe-Ti oxides (Carmichael 1991), and with those obtained from Mössbauer spectroscopy on synthetic basaltic liquids and glasses (Partzsch et al. 2004).

The values of $\triangle \mathrm{NNO}$ for the scoria and lavas from the various Colima cones are given in Table 1 and are plotted in Figs. 4 and 5. The new ferric-ferrous analyses for most of the basanite, leucite-basanite, and minette samples (Table 1) lead to $\triangle \mathrm{NNO}$ values between 2 and 4 , which are similar to those obtained for the olivine minette lavas from the Mascota volcanic field (Carmichael et al. 1996). This range is about two orders of magnitude higher than is typical of calc-alkaline arc magmas from west-central Mexico (Fig. 4). The one exception is the basanite from the Apaxtepec cone, the youngest of all the Colima cones, which has a $\triangle N N O$ value of 0.7 . The new leucite basanite sample taken from a recent road cut (sample 1015 from La Erita) is strikingly fresh, and its $\triangle \mathrm{NNO}$ value of 3.0 is very likely pristine. In Fig. 5, a plot of $\Delta \mathrm{NNO}$ vs. Ba is shown for all the samples from this study (all olivinebearing) as well as the olivine minettes and basaltic andesites (all olivine-bearing) from the Quaternary Mascota field (Lange and Carmichael 1990; Carmichael et al. 1996). The positive correlation between $\triangle \mathrm{NNO}$ and Ba strongly suggests that the redox state of the Colima cones reflects 


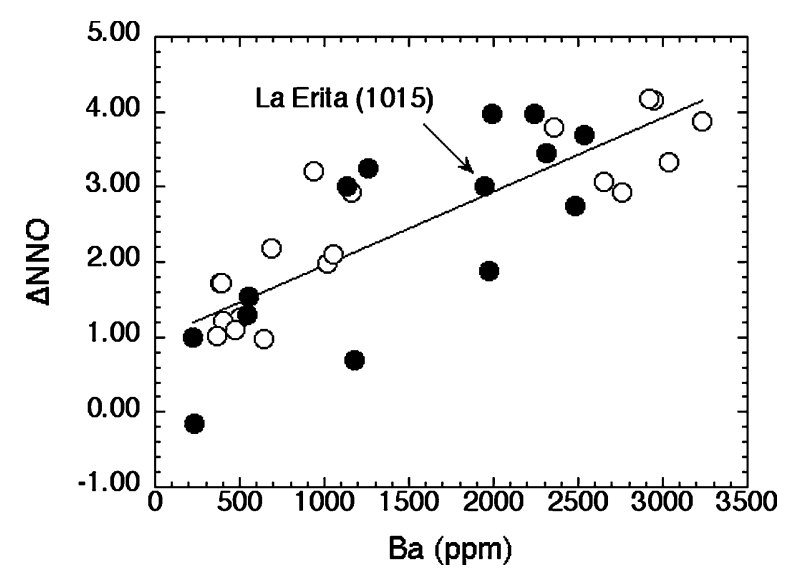

Fig. 5 Plot of $\triangle \mathrm{NNO}$ vs. Ba (ppm) for all samples in Tables 1 and 2 (solid circles) and olivine-bearing minettes and basaltic andesites (open circles) from Mascota (Carmichael et al., 1996). The linear regression to the data shows a positive correlation between $\triangle \mathrm{NNO}$ and $\mathrm{Ba}$ concentration, both of which reflect the influence of slabderived fluids. The freshest sample collected in this study (La Erita, sample 1015) has a $\triangle \mathrm{NNO}$ value of 3.0 , which closely represents the pre-eruptive magmatic value and not the effects of post-eruptive weathering

the influence of a highly oxidized, slab-derived fluid, which probably formed phlogopite-bearing veins within the subarc mantle (Carmichael et al. 1996). Therefore, the $\triangle \mathrm{NNO}$ values of 2-4 for the potassic magmas erupted from the Colima cones represent, to first order, magmatic values and are not the result of post-eruptive weathering and oxidation.

The most significant change from the results given in Luhr and Carmichael (1981) is for sample 22E, one of the few basalts in western Mexico, which comes from the pervasively oxidized Tezontal scoria cone. After a lengthy search we found a rare example of a dense black core in a volcanic bomb, which was analyzed (Table 1). This unoxidized sample is more reduced $(\triangle \mathrm{NNO}=1.0)$ than the original, thoroughly red and oxidized sample $(\triangle \mathrm{NNO}=2.5)$ analyzed by Luhr and Carmichael (1981). We consider this lower oxidation state to be more representative of the rare examples of Quaternary basaltic magma in western Mexico.

Sulfur concentration and release on eruption

A wide variety of experiments in the literature show that sulfur solubility in silicate liquids is a strong function of oxidation state and that sulfur dissolves primarily as sulfate species under oxidizing conditions ( $>\mathrm{Ni}-\mathrm{NiO}$ buffer) (Carroll and Webster 1994). Moreover, under these oxidizing conditions, the solubility of sulfur increases with oxidation state (Katsura and Nagashima 1974). Thus it is plausible that the highly oxidized magmas erupted from the Colima cones may have contained substantial concentrations of dissolved sulfate.

Although sulfur is presently being deposited in the active summit crater of Volcán Colima, sulfur-bearing minerals are rare in Quaternary calc-alkaline volcanic rocks from western Mexico, although pyrrhotite has been found in a series of high- $\mathrm{Mg}$ andesites from central Mexico (Blatter and Carmichael 2001). Alkaline magmas, particularly minettes (Carmichael et al. 1996) and trachybasalts (Luhr and Carmichael 1985; Barclay and Carmichael 2004) often have microphenocrysts of apatite, so that part of the magmatic sulfur will be retained on eruption, because sulfate is incorporated in the apatite structure (Peng et al. 1997; Parat and Holtz 2004). Two apatite crystals in Colima leucite-basanites contain 1.21 and 0.96 wt.\% $\mathrm{SO}_{3}$ (Luhr and Carmichael 1981), greater than the amount found in apatite $(0.34 \mathrm{wt} . \%)$ coexisting with anhydrite and pyrrhotite in the trachyandesite scoria of the 1982 eruption of El Chichón, SE Mexico (Luhr et al. 1984). However anhydrite, which accounts for the majority of the $S$ in fresh El Chichón pumices, has not yet been found (as of 2005) in any young volcanic rocks from west-central Mexico. The $\mathrm{SO}_{3}$ contents of the analyzed Colima alkaline samples are given in Table 1, and despite the large concentrations in the apatite phenocryst analyses noted above, the levels in the lavas are always less than $0.25 \mathrm{wt} . \%$, far lower than the amount (1.2 wt.\%) in the fresh El Chichón pumices (Luhr et al. 1984). However, we note that Maria and Luhr (2004) analyzed up to 2.3 wt. $\% \mathrm{SO}_{3}$ in olivine melt inclusions in minette and basanite scoria from Mascota and Colima cones. The highest concentration of whole-rock $\mathrm{SO}_{3}$ so far found in western Mexico is 0.59 wt. \% for biotite-bearing trachybasalt bombs (MAS 2003a, Table 2; Barclay and Carmichael 2004) from the Pleistocene cone Cerro La Pilita, close by the historically (1759-1774) active Volcán Jorullo (Luhr and Carmichael 1985).

Eruptions of anhydrite-bearing magmas at El Chichón (Luhr et al. 1984) and Pinatubo (Westrich and Gerlach 1992, Gerlach et al. 1996) were accompanied by large

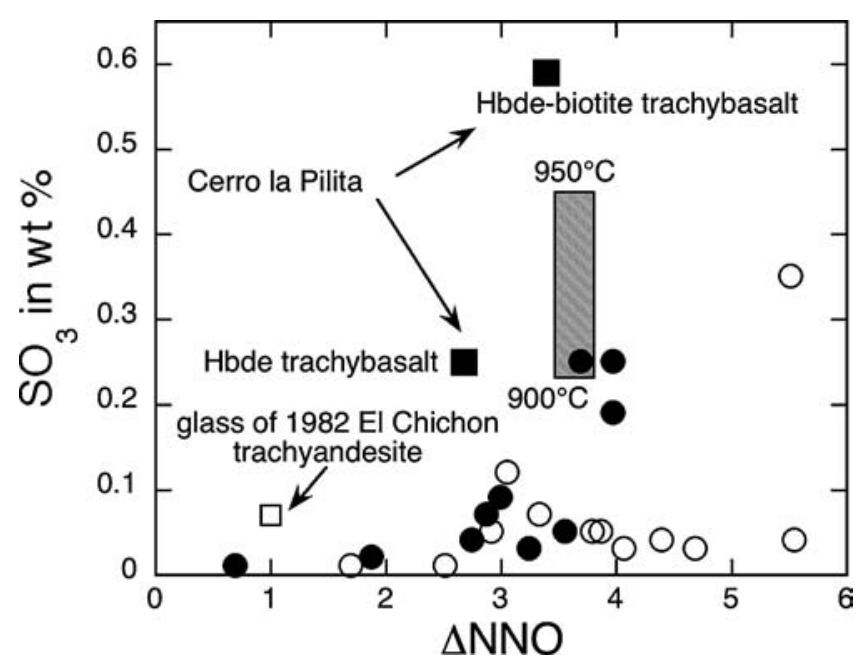

Fig. 6 Plot of $\triangle \mathrm{NNO}$ against measured $\mathrm{S}$ concentrations, calculated as $\mathrm{SO}_{3}$ in alkaline lavas from west-central Mexico. The ornamented rectangle shows the range of $\mathrm{SO}_{3}$ solubilities in liquids equilibrated with anhydrite at $\Delta \mathrm{NNO} \sim 3.6\left(\mathrm{Mn}_{3} \mathrm{O}_{4}\right.$ - $\mathrm{MnO}$ buffer, hausmannitemanganosite) at two different temperatures at $2 \mathrm{~kb}$ for a basaltic andesite from Volcan Jorullo (Luhr 1990). Data are taken from Tables 1 and 2, and unpublished analyses of $\mathrm{S}$ in alkaline lavas from Mascota, western Mexico (Carmichael et al. 1996) 
injections of $\mathrm{SO}_{2}$ into the atmosphere, estimated at 7 and 20 megatons respectively (Bluth et al. 1992). Thus the question arises about the sulfate concentration of these alkaline magmas from west-central Mexico, and whether they were saturated with anhydrite (or emitted significant amounts of $\mathrm{SO}_{2}$ ) on the day of their eruption. Anhydrite is stable at relatively high oxygen fugacities, $\Delta \mathrm{NNO}>1.0-1.5$, (Carroll and Rutherford 1987) and anhydrite-saturated magmas worldwide have the following features: they are highly oxidized, crystal-rich, fluid saturated, with abundant hornblende or biotite (Peng et al. 1997). However, anhydrite rarely survives in the geologic record as it is very soluble in water and can disappear from surface flows after several rainstorms.

From the data reported in Carroll and Webster (1994), magmas with values of $\Delta \mathrm{NNO}>1$ will have $80 \%$ or more of the sulfur dissolved as sulfate. Thus we have plotted measured concentrations of $\mathrm{S}$, calculated as $\mathrm{SO}_{3}$, against $\triangle \mathrm{NNO}$ for these alkaline lavas (Tables 1,2) and compared them to El Chichón in Fig. 6. The data in Fig. 6 include the $\mathrm{SO}_{3}$ content of the matrix glass of El Chichón, which was in equilibrium with anhydrite, and the sulfate solubilities in a basaltic andesite (Table 2 , JOR 44) at $900-950{ }^{\circ} \mathrm{C}$ in equilibrium with anhydrite (Luhr 1990). A plausible speculation from these $\mathrm{SO}_{3}$ concentrations (and the melt inclusion study of Maria and Luhr 2004) is that the alkaline magmas, prior to eruption, had substantial amounts of

dissolved $\mathrm{SO}_{3}$ at levels appropriate to stabilize anhydrite. However, whether anhydrite was ever present in the scoria or lavas remains an open question.

Nevertheless, it is conceivable that significant amounts of $\mathrm{SO}_{2}$ were released to the atmosphere by the eruption of the Colima alkaline magmas. Although their aggregate volume (Table 4) exceeds that of the 1982 El Chichón eruption $\left(\sim 0.4 \mathrm{~km}^{3}\right)$, the precision of their measured ages (Table 3 ) shows that they were erupted episodically over a prolonged time interval ( $\sim 180 \mathrm{kyr}$; Fig. 3$)$, so that there was a sequential rather than an abrupt release of sulfur gases to the atmosphere. As the solubility of sulfur in basic magmas is a strong function of oxygen fugacity (Katsura and Nagashima 1974), with a solubility minimum at $\Delta \mathrm{NNO}=0$, highly oxidized alkaline magmas associated with subduction are the principal means of transporting sulfur (as sulfate) from the modified mantle wedge to the Earth's atmosphere.

Acknowledgements The XRF analyses were made by Laura Glaser and Tim Teague of UC Berkeley, and the development of the procedure to measure $\mathrm{S}$ in these samples is due to them. We thank Marcus Johnson for his assistance in the Ar geochronology lab at the University of Michigan. Insightful comments by Jim Luhr, Mac Rutherford, and Julie Donnelly-Nolan substantially improved this manuscript. This research was supported the National Science Foundation: EAR0228919 to ISEC and EAR-9909567 to RAL

\section{Appendix}

Table A Key to sample numbers

\begin{tabular}{|c|c|c|c|c|}
\hline Cinder cone & $\begin{array}{l}\text { Sample \# } \\
\text { (this study) }\end{array}$ & Description (this study) & Sample \# (LC 1981) & Description (LC 1981) \\
\hline$\overline{\text { Apaxtepec }}$ & $1001 \mathrm{~B}$ & lava from associated flow & $1004-500 / 501$ & scoria from cone \\
\hline Usmajac & 1002 & dense interior of bomb from scoria cone & SAY 17B & dense bomb from scoria cone \\
\hline La Erita (minor cone) & 1003B & lava (not scoria) from minor cone & SAY 5A & lava underlying scoria \\
\hline Telcampana & $1005 \mathrm{~A}$ & massive lava from cone & $1004-507 / 508$ & scoria from cone \\
\hline Comal Chico & $1006 \mathrm{~B}$ & dense interior of bomb from scoria cone & SAY 8G/8H & scoria from cone \\
\hline Comal Grande & 1008B & lava block from cone & not sampled & \\
\hline San Isidro & 1013 & dense interior of bomb from scoria cone & SAY $6 A, 6 D, 6 E$ & scoria from cone \\
\hline La Erita (main cone) & 1015 & vesicular lava from main cone & $1004-511$ & large bomb among cinder \\
\hline Cuauhtemoc & 1016 & lava from cone & $1004-510$ & scoria from cone \\
\hline Tezontal & $22 \mathrm{E}$ & dense bomb analyzed; lava flow dated & SAY 22E & dense bomb from scoria cone \\
\hline
\end{tabular}

LC (1981) is Luhr and Carmichael (1981) 


\section{References}

Allan JF (1986) Geology of the northern Colima and Zacoalco grabens, southwest Mexico: Late-Cenozoic rifting of the Mexican volcanic belt. Geol Soc Am Bull 97:473-485

Barclay J, Carmichael ISE (2004) A hornblende basalt from western Mexico: water-saturated phase relations constrain a pressuretemperature window of eruptibility. J Petrol 45:485-506

Blatter DL, Carmichael ISE (1998) Plagioclase-free andesites from Zitacuaro (Michoacan), Mexico: petrology and experimental constraints. Contrib Mineral Petrol 132:121-138

Blatter DL, Carmichael ISE (2001) Hydrous phase equilibria of a Mexican high-silica andesite: A candidate for a mantle origin? Geochim Cosmochim Acta 65:4043-4065

Blatter DL, Carmichael ISE, Deino AL, Renne PR (2001) Neogene volcanism at the front of the central Mexican volcanic belt: basaltic andesites to dacites, with contemporaneous shoshonites and high- $\mathrm{TiO}_{2}$ lava. Geol Soc Am Bull 113:1324-1342

Bluth GJ, Doiron SD, Schnetzler CC, Krueger AJ, Walter LS (1992) Global tracking of the $\mathrm{SO}_{2}$ clouds from the June, 1991 Mount Pinatubo eruptions. Geophys Res Lett 19:151-154

Carmichael ISE (1991) The redox states of basic and silicic magmas: A reflection of their source regions? Contrib Mineral Petrol 106:129-141

Carmichael ISE, Lange RA, Luhr JF (1996) Quaternary minettes and associated volcanic rocks of Mascota, western Mexico: a consequence of plate extension above a subduction modified mantle wedge. Contrib Mineral Petrol 124:302-333

Carroll MR, Rutherford MJ (1987) The stability of igneous anhydrite: experimental results and implications for sulfur behavior in the $1982 \mathrm{El}$ Chichon trachyandesite and other evolved magmas. J Petrol 28:781-801

Carroll MR, Webster JD (1994) Solubilities of sulfur, noble gases, nitrogen, chlorine and fluorine in magmas. In: Carrol MR, Holloway JR (eds) Volatiles in Magmas. Rev Mineral 30:231-279

Christie DM, Carmichael ISE, Langmuir CH (1986) Oxidation states of mid-ocean ridge basalt glasses. Earth Planet Sci Lett 79:397-411

Colton HS (1967) Cinder cones and lava flows. Museum of Northern Arizona, Flagstaff, Arizona, pp 1-58

Delgado Granados H. (1993) Late Cenozoic tectonics offshore western Mexico and its relation to the structure and volcanic activity in the western Trans-Mexican Volcanic Belt. Geofís Int 32:543-559

DeMets C Stein S (1990) Present-day kinematics of the Rivera plate and implications for tectonics in southwestern Mexico. J Geophys Res 95:21931-21948

Fries C (1953) Volumes and weights of pyroclastic material, lava, and water erupted by Parícutin volcano, Michoacán, Mexico. Trans Am Geophys Union 34:603-616

Frey HM, Lange RA, Hall CM Delgado Granados H (2004) Magma eruption rates constrained by ${ }^{40} \mathrm{Ar} /{ }^{39} \mathrm{Ar}$ chronology and GIS for the Ceboruco-San Pedro volcanic field, western Mexico. Geol Soc Am Bull 116:259-276 (Errata 116:1040)

Gerlach TM (1993) Oxygen buffering of Kilauea volcanic gases and the oxygen fugacity of Kilauea basalt. Geochim Cosmochim Acta 57:795-814

Gerlach TM, Westrich HR, Symonds RB (1996) Preeruption vapor in magma of the climactic Mount Pinatubo eruption: source of the giant stratospheric sulfur dioxide cloud. In: Newhall CG, Punongbayan RS (eds) Fire and mud: eruptions and lahars of Mount Pinatubo, Philippines. University of Washington Press, Seattle, 415-433

Hall CM, Farrell JW (1995) $\operatorname{Laser}^{40} \mathrm{Ar} /{ }^{39} \mathrm{Ar}$ ages of tephra from Indian Ocean deep-sea sediments: tie points for the astronomical and geomagnetic polarity time scales. Earth Planet Sci Lett 133:327-338

Hasenaka T, Carmichael ISE (1987) The cinder cones of MichoacanGuanajuato, central Mexico: petrology and chemistry. J Petrol 28:241-269
Johnson CA, Harrison CGA (1990) Netectonics in central Mexico. Phys Earth Planet Int 64:187-210

Katsura T, Nagashima S (1974) Solubility of sulfur in some magmas at 1 atmosphere. Geochim Cosmochim Acta 38:517-531

Kilinc A, Carmichael ISE, Rivers ML, Sack RO (1983) The ferric-ferrous ratio of natural silicate liquids equilibrated in air. Contrib Mineral Petrol 83:136-140

Kress VC, Carmichael ISE (1988) Stoichiometry of the iron oxidation reaction in silicate melts. Am Mineral 73:12671274

Kress VC, Carmichael ISE (1991) The compressibility of silicate liquids containing $\mathrm{Fe}_{2} \mathrm{O}_{3}$ and the effect of composition, temperature, oxygen fugacity and pressure on their redox states. Contrib Mineral Petrol 108:82-92

Lange RA, Carmichael ISE (1990) Hydrous basaltic andesites associated with minette and related lavas in western Mexico. J Petrol 31:1225-1259

Lange RA, Carmichael ISE Hall CM (2000) ${ }^{40} \mathrm{Ar} /{ }^{39} \mathrm{Ar}$ chronology of the Leucite Hills, Wyoming: eruption rates, erosion rates, and an evolving temperature structure of the underlying mantle. Earth Planet Sci Lett 174:329-340

Luhr JF (1990) Experimental phase relations of water-saturated and sulfur-saturated arc magmas and the 1982 eruptions of El Chichón Volcano. J Petrol 31:1071-1114

Luhr JF, Carmichael ISE (1980) The Colima volcanic complex, Mexico: Part I. post-caldera andesites from Volcan Colima. Contrib Mineral Petrol 71:343-372

Luhr JF, Carmichael ISE (1981) The Colima Volcanic complex, Mexico: Part II. Late Quaternary cinder cones.. Contrib Mineral Petrol 76:127-147

Luhr JF, Carmichael ISE (1982) The Colima volcanic complex, Mexico: Part III. ash and scoria fall deposits from the upper slopes of Volcan Colima. Contrib Mineral Petrol 80:262275

Luhr JF, Carmichael ISE (1985) Jorullo volcano, Michoacan, Mexico (1759-1774): the earliest stages of fractionation in calc-alkaline magmas. Contrib Mineral Petrol 90:142-161

Luhr JF, Prestegaard KL (1988) Caldera formation at Volcano Colima, Mexico by a large Holocene volcanic debris avalanche. J Volcanol Geoth Res 35:335-348

Luhr JF, Carmichael ISE, Varekamp JC (1984) The 1982 eruptions of El Chichon volcano, Chiapas, Mexico: mineralopy and petrology of the anhydrite-bearing pumices. J Volcanol Geotherm Res 23:69-108

Luhr JF, Allan JF, Carmichael ISE, Nelson SA Hasenaka T (1989) Primitive calc-alkaline and alkaline rock types from the western Mexican Volcanic Belt. J Geophys Res 94:4515-4530

MacLeod NS, Sherrod DR, Chitwood LA, Jensen RA (1995) Geologic map of Newberry volcano, Deschutes, Klamath,and Lake Counties, Oregon. USGS Map I-2455

Maria AH, Luhr JF (2004) Melt inclusions in Late-Quaternary basanites and minettes of the Colima Rift and Mascota Volcanic Field (western Mexican Volcanic Belt). In: Aguirre-Díaz GJ, Macías-Vásquez JL, Siebe C (eds) Neogene-Quaternary continental margin volcanism. Proceedings of the GSA Penrose Conference at Metepec, Puebla, Mexico, p 49

Parat F, Holtz F (2004) Sulfur partitioning between apatite and melt and effect of sulfur on apatite solubility at oxidizing conditions. Contrib Mineral Petrol 147:201-212

Partzsch GM, Lattard D, McCammon C (2004) Mossbauer spectroscopic determination of $\mathrm{Fe}^{3+} / \mathrm{Fe}^{2+}$ in synthetic basaltic glass: a test of empirical $\mathrm{f}_{\mathrm{O} 2}$ equations under superliquidus and subliquidus conditions. Contrib Mineral Petrol 147:565580

Peng G, Luhr JF, McGee JJ (1997) Factors controlling sulfur concentrations in volcanic apatite. Amer Mineral 83:1210-1224

Renne PR, Swisher CC, Deino AL, Karner DB, Owens TL, DePaolo DJ (1998) Intercalibration of standards, absolute ages, and uncertainties in ${ }^{40} \mathrm{Ar} /{ }^{39} \mathrm{Ar}$ dating. Chem Geol 145:117-152

Righter K, Rosas-Elguera J (2001) Alkaline lavas in the volcanic front of the western Mexican Volcanic Belt: geology and petrology of the Ayutla and Tapalpa volcanic fields. J Petrol 42:2333-2361 
Robin C, Mossand P, Camus G, Cantagrel JM, Gourgaud A Vincent PM (1987) Eruptive history of the Colima volcanic complex (Mexico). J Volcanol Geotherm Res 31:99-113

Sack RO, Carmichael ISE, Rivers M, Ghiorso MS (1980) Ferricferrous equilibria in natural silicate liquids at 1 bar. Contrib Mineral Petrol 75:369-376

Samson SD Alexander EC (1987) Calibration of the interlaboratory ${ }^{40} \mathrm{Ar} /{ }^{39} \mathrm{Ar}$ dating standard, Mmhb-1. Chem Geol 66:27-34

Taylor JR (1982) An introduction to error analysis: the studies of uncertainty in physical measurements. University Science Books, Mill Valley, California, pp 1-270

Walker GPL (1973) Explosive volcanic eruptions: a new classification scheme. Geol Rund 62:431-446

Wallace PJ, Carmichael ISE (1992a) Alkaline and calc-alkaline lavas near Los Volcanes, Jalisco, Mexico: geochemical diversity and its significance in volcanic arcs. Contrib Mineral Petrol 111:423-439
Wallace PJ, Carmichael ISE (1992b) Sulfur in basaltic magmas. Geochim Cosmochim Acta 56:1863-1874

Wallace PJ, Carmichael ISE (1999) Quaternary volcanism near the Valley of Mexico: implications for subduction zone magmatism and the effects of crustal thickness variations on primitive magma compositions. Contrib Mineral Petrol 135:291314

Westrich HR, Gerlach TM (1992) Magmatic gas source for the atmospheric $\mathrm{SO}_{2}$ cloud from the June 15, 1991, eruption of Mount Pinatubo. Geology 20:867-870

Wood CA (1980) Morphometric analysis of cinder-cone degradation. J Volcanol Geotherm Res 8:137-160 